\title{
IDENTIFY MAIN FACTORS THAT INFLUENCE CORRUPTION AND SUGGEST HOW TO ERADICATE THE CORRUPTION PROBLEM IN INDONESIA $^{1}$
}

\author{
Subagio \\ Indonesia's Corruption Eradication Commision \\ E-mail: sbgogik@gmail.com
}

\author{
ARTICLE INFORMATION \\ Article history: \\ Received July 31, 2015 \\ Revised November 30,2015 \\ Accepted January 05, 2016

\section{JEL Classifications} \\ K49

\section{Key Words:} \\ Ccorruption, \\ Eradication, \\ Prevention, \\ Law enforcement, \\ Politic. \\ DOI: \\ 10.21532/apfj.001.16.01.01.03
}

\begin{abstract}
Ccorruption is an extra ordinary crime which has complex problem. There are many causes of corruption; and ccorruption has negative impact to many sectors, which is causing huge losses to the state and society. During the last decade, since the Corruption Eradication Commission (CEC) of the Republic of Indonesia has been established, the eradication of corruption cases has been done massively. However, the amount of corruption cases which have been handled by law enforcement agencies tend to increase by year to year. This paper will identify what factors are causing corruption and provide the ideas how to eradicate the corruption in Indonesia. There are at least five factors that cause corruption in Indonesia. The first one is politic factor. Secondly, is ineffective of system. The third is incentive or financial pressure factor. The fourth is due to the weak of law enforcement. The last of corruption causes is lack of integrity. This paper also provides the problem solving of corruption which is a latent endemic problem in Indonesia based on law number 30 of 2002 and identify the main causes of corruption. By identifying the root causes of corruption, hopefully it can be expected for eradicating corruption effectively and efficiently.
\end{abstract}

\section{INTRODUCTION}

Corruption is a big public problem in Indonesian. It is not only marked by rampant corruption committed by public officials in the bureaucrats, but also it is evident based on research conducted by Transparency International. According to Transparency International (2015), the recent research shows that Indonesia was ranked 107 from 174 countries surveyed around the world, with Index Perception
The Winner of 2015 Call for Papers of ACFE Indonesia Chapter
Volume 1, No. $1^{\text {st }}$ Edition (January-June 2016) 
Corruption (IPC) is 34 compared to Singapore which achieved an IPC of 84 as the cleanest country from corruption in the South East Asian Nations (ranked 7 around the world). The IPC value under fivety is categorized as highly corrupt countries (Transparency International, 2015). While Indonesia is categorized as one of the most corruptive countries in the Asia, Singapore is considered the cleanest from corruption in the Asia countries. This paper will depict the big problem of corruption in Indonesia was created by some causes such as political factor, factor of system, financial pressure, law enforcement, and lack of integrity. It is also suggested several actions to address the problem solvers for eradicating corruption based on causes of corruption and law number 30 of 2002, which are legal action, prevention, monitor, coordination, and supervision.

\section{THEORETICAL BACKGROUND}

A. Factor of politic.

The first cause of corruption in Indonesia is politic factor. Politic is closely related to power; and power tends to corrupt (Heidenheimer \& Johnston 2008; Kuncoro 2006). According to Rama (2012), corruption occurs because of the practice of politics in which governments or authorities interact in a closed between public and private sector. In closure, the political and economic transactions take place only for the sake of a handful of interest groups involved in it. The existence of conspiracy is a great opportunity for the authorities so that the law seems to have been held by a certain power. Further, Newman (2011) argued that the main cause of corruption in Indonesia is money politics and the abuse of power by politic elites and legislative members. The similar argumentation is expressed by Newman (2011), who stated that either the legislative elections, as well as the head of region, all of which are well supported candidates of the political parties have to spend a lot of money for campaign expenses. When they are selected as legislative members or head of the region, they have to return their money had been spent with shortcuts. They abused their power to take the state money through illegal means. Suroso (2014) indicated that $69,7 \%$ Indonesian officials who conduct corruption during 2009 to 2014 are political leaders and parliament members. The table below shows the number of legislative members and head of regions, who committed or involved in corruption from 2009 until 2014 (handled by the CEC). The amount of legislative members are both central and region legislative members; and the head of regions are included governors, majors, and regents.

\begin{tabular}{|l|c|c|c|c|}
\hline No. & Year & $\begin{array}{c}\text { Legislative } \\
\text { members }\end{array}$ & $\begin{array}{c}\text { Head of } \\
\text { Regions }\end{array}$ & Total \\
\hline 1 & 2009 & 8 & 7 & 15 \\
\hline 2 & 2010 & 27 & 5 & 32 \\
\hline 3 & 2011 & 5 & 4 & 9 \\
\hline 4 & 2012 & 16 & 4 & 20 \\
\hline 5 & 2013 & 8 & 5 & 13 \\
\hline 6 & 2014 & 3 & 15 & 18 \\
\hline & Total & 67 & 40 & 107 \\
\hline
\end{tabular}

(source: http://acch.kpk.go.id) 


\section{B. Corruption due to in-effective systems} Another factor that causes corruption in Indonesia is the in-effective systems. System is a set of detailed methods, procedures, and routines created to carry out a specific activity that contains of interrelated and interdependent elements (Baltzan et al. 2010). There are a lot of systems that cause potential of corruption such as the system of payroll, recruitment system, internal control system, system of procurement of goods and services of the government, system of public administration, legal system, management information system, budgeting system, and accounting system. Macmillan (2011) stated that if those systems are in-effective, people easily conduct corruption because there are opportunities for doing fraud. For instance, when the system of procurement of goods and services is ineffective, this causes rampant bribery, poor quality goods and poor sense of justice. The payroll system which is un-fair creates justify for doing corruption. When the recruitment system is in-effective, it creates bribery and employees who are elected not the best personil. The Poor of internal control system and the powerless internal audit create an opportunity for someone to do corruption. People, who previously had no intention of corruption, may conduct corruption if there are opportunities available. Related to Indonesia country, Macmillan (2011) implied that the weakness of internal control is the key element way so many corruptions occur. For instance, in the term of politic, there is no segregation of duties between the leader of party and executive officers. It is suggested that since the party leader appointed as minister, the political leader should resign as chairman of the party.

C. Corruption due to financial pressure.

The next cause of corruption in Indonesia is financial pressure. According to Turner (2003), corruption is closely related to money. If someone needs money to fulfil their needs, they do whatever they can for earning money in considerable amounts in as easy way as possible. The similar opinion is expressed by Macmillan (2011), who stated that corruption is the result of a condition in which is a person's situation requires more income, or feel less of what he gained when doing business in ways that are legitimate. Financial pressure can cause a person to commit acts of corruption. They will try to earn money from a variety of ways. One of the easiest ways is by doing corruption. Macmillan (2011) also argued that the main cause of corruption in Indonesia is the low salaries of civil servants. They are required to meet the needs of life which is very expensive (especially in big cities), while the amount of income cannot meet their basic needs. However, this argumentation is disputed by Newman (2011), since most of corruption in Indonesia is corruption by greedy not by need. In most of corruption cases which handled by law enforcements agencies the perpetrator of corruption are people who gained high level of income. 
D. Weak of law enforcement

The other main factor why people behave corruption is weak law enforcement. Pakdel, Damirchi, and Gholizadeh (2012) argued that the lack of law enforcement can cause of the rampant corruption in developing countries. They explained when there is no punishment for perpetrator of corruption; they justify their acts of corruption because everyone else is doing the same thing. It is like the broken windows theory, as stated by Greene (1999) who implied that if someone broke windows, and then left alone, and then others also did destroy the window. They will freely enter into the house through the window and take valuable items in the house for their personal interests. In addition, Newman (2011), stated that although there is attempting from the government to achieve a clean government free from corruption, collusion and nepotism, in fact, corruption is still rampant and bribery going on everywhere. For example, when someone violates traffic rules, that person easily bribe the traffic police so he or she free from fines and penalties.

\section{E. Lack of Integrity}

Acccording to Komarudin(2006), the root of the problem of corruption in the Indonesian bureaucracy is the lack of integrity of the state apparatus, so integrity plays a pivotal role in preventing corruption. Integrity contains good quality of moral and attitude, good character (such as honesty, wise and justify) that showed unity so they are doing the right thing in all circumstances. There are two aspects of integrity, which needs commitment and consistency (Pope 2000; Kuncoro 2006). Therefore, strengthening the integrity needs to be encouraged continuesly. For instance by signing the pact of integrity for public officials and politic elites before starting their tasks. Moreover, for maintaing the commitment of integrity, the country's leaders and political elites must set an example with a simple lifestyle and clean behavior. Komarudin (2006) suggested that the implementation of law enforcement policy without the integrity of government officials will lead to corruption risk. Pope (2000) found that integrity can be implemented individually, in group (family and organization), and national. Pope (2000) offered national integrity system for preventing corruption. Discussion about national integrity system will be explained briefly in the sub title "prevention" below.

\section{SUGGESTIONS AND DISCUSSIONS}

According to Kwok (2007) the Independent Commission Againt Corruption (ICAC) implemented three strategies for eradicating corruption in Hongkong. The strategies are conducting investigation, prevention, and education. In Indonesia, based on article 6 law number 30 of 2003, the CEC has five tasks for eradicating corruption. The tasks assignment are as follows:

A. Conducting initial investigations, investigations, and prosecutions againts criminal acts of corruption. These strategies are called as repression strategy, law 
enforcement, or legal actions. In fact, the stages of repression is like a running wheel which is starting with initial investigations and ending with executions. The stage of the initial investigation can be conducted by reporting the incidence of corruption and collecting preliminary evidence. The CEC can tap into communication lines and record conversations in order to collect evidences. The most important thing is that the CEC at least must collect two evidences before assigning someone as a suspect. The further investigation is by calling witnesses/suspect, banning foreign travel for the suspect, inquiring information about financial transaction of suspect, blocking the account of suspect, requesting data on the wealth and tax details, requesting assistance from the police or other relevant institutions to conduct searches, arrests, and confiscations. Attempts of prosecution are made to the suspects of corruption in court by the public prosecutor, while the execution phase should be done if it has been out of the judge's decision legally binding.

\section{Discussions.}

Repression strategy for combating corruption will not only be expected cause a deterrent effect, but also can return the loss of state finance. In order to create a deterrant effect, the law enforcements must conduct legal actions fairly and punish the perpetrator of corruption cases with appropriate sentences. As noted in the breaking windows theory, Newman (2011) stated that if a crime is not dealt with properly, other crimes will occur. Similarly, if corruption crimes are not punished with appropriate penalties, people will attempt to commit corruption continuously. For that action against the perpetrators of corruption are absolutely necessary in order to create deterrent effect. Moreover, according to Brereton (1999), the crime of corruption can be eradicated through law enforcement effectively and zero tolerance policy. The term of this policy indicated that no matter how small the crime committed by someone, law enforcement institutions must enforce the perpetrator of crime fairly and equitably (Brereton 1999). The other side of law enforcement strategy is returning the loss state finance. During a decade since the CEC has been established, the CEC success for saving and depositing in to the state treasury more than one trillion from eradicating of corruption. The amount money are including the compensation of state loss finance from law enforcement activities and gratification.

\section{B. Prevention}

Although the law enforcement is expected to be a deterrent effect, the best way to fight corruption is through prevention. As what happen in medical study, it would be better to prevent than cure. There are some strategies for preventing corruption. According to artice 13 law number 30 of 2002, the CEC has authority for preventing 
corruption through six actions. The actions are:

1) Conducting registration and examination of wealth report from public officials;

2) Receiving report and deciding the status of gratification;

3) Implementing anti corruption program on every level of education;

4) Designing and supporting the implementation of socialization program for eradicating corruption;

5) Conducting anti corruption campaign to the public;

6) Conducting mutual cooperation both bilateral or multilateral for eradicating corruption.

The six tasks of prevention above are deliveredinto Directorate ofInventorizations and Examinations of Wealth Report of Government Executives, Directorate of Gratification, Directorate of education and public service, and Directorate of Fostering Networks between Commissions and Institutions, respectively in the organization structure of the CEC.

\section{DISCUSSIONS}

In order to enhance transparency and accountability, the CEC is not only conducting registration and examination of wealth report from public officials but also receiving report and deciding the status of gratuity. The main purpose of wealth report and gratification report are preventing the public officials from receiving asset illegally. The reason for this is that by registering and declaring their wealth to the CEC and public, the CEC can examine the origin of wealth and public can value the fairness wealth of public officials. Furthermore, by reporting gratuity which is not more than thirty days since they received gratification, the public officials are prevented from lawsuits. The most important thing about gratuity is that do not receive payment/gratification that encourage them to do something or not to do anything in relation to their position or in violation of their obligation. When the states apparatus or civil servants hesitate (in grey area), they can report their gratification not more than thirty days since they received gratification. These two actions create enhancing transparency and accountability. Transparency and accountability are two main characteristics of good governance (Rama 2012; Yap Kioe Sheng 2015). Transparency means that the decision is not only taken in manner by following rules and regulations, but also that information about the policy decison and activities are provided easily understandable (Yap Kioe Sheng 2015). Gustav et al. (2014) pointed out that transparency plays a pivotal role in reducing corruption in Indonesia. By enhancing the transparency, public can access and monitor the policy process and it's implementation. The CEC has developing wealth reports of the public officials and gratuities report through e-report. The main reason for these reports are providing the form through web base, so public aofficials can report from anywhere easily. The CEC also support the e-procurement process of procurement goods and services. The purpose of implementation e-procurement is not only for preventing corruption but also 
enhancing the quality of goods and services. By implementing e-procurement, it can reduce the potential for convergence between the procurement committe and the vendors which create competition fairly and reduce high cost economy or bribery. The CEC also support the transparency of budgetting which was be implemented in several provincis and distrisct such as Governor of Special District of Jakarta. Moreover, the other main characteristic of good governance is accountability(Yap Kioe Sheng 2015). Margareth (2015) suggested that accountability plays a pivotal role in preventing the corruption in political elites and bureaucrats. She implied that financial accountability is not only responsiblity to the people in making use the budget in line with the budget plans and allocation but also that the using of budget can provide benefits to the public. According to Tanthowi et al. (2005), in combating corruption in Indonesia need three kinds of accountabilities. First of all is horizontal accountability by growing mutual observing and monitoring among government officials. Secondly is vertical accountability through elections and civil society. Lastly is external accountability in the form of support from public and the international communities.

In addition, Directorate of Education and Public Service of CEC plays important role in handling implementation anti corruption program on every level of education, design and support the implementation of socialization program for eradicating corruption, and implementation anti corruption campaign to the public. Related to this task, Gustav et al. (2014) stated that enhancing public awareness through education is essential for preventing corruption. Public education about anti corruption awareness must continue to be refined. In the term of political education, the CEC has been educating three stake- holders. The three components are the instituons of elections, political parties, and public voters. The purpose of political education is strengthening political system integrity which intends to establish a political system that emphasizes ethics, morals, not corrupt, and concerned with the wider community.

Further, related to conduct mutual cooperation both bilateral or multilateral for eradicating corruption, the CEC has handled in coordination of Directorate of Fostering Networks between Commissions and Institutions. Besides making coordination with international institutions, the CEC has established cooperation with anti corruption agencies from other countries such as Malaysian Anti Corruption Commission (MACC), Independence Commission Against Corruption (ICAC) Hongkong, Timor Leste's Commissao Anti-Corrupcao, and Kuwait Anti Corruption Authority. In this case, the ADB (2011) stated that it is important to cooperate in preventing and combating corruption between countries and between countries with international institutions. Hamzah (2006) argued that corruption is global problem, so country who conduct international cooperation will receive advantages. There are at least three benefits when country open minded to international cooperation. First is extradition 
benefit. Secondly, it can return the asset from the prepetrator of corruption in other country. Lastly, the information benefits (Hamzah 2006). Rama (2012) pointed out that by doing international cooperation, the country can receive informationa and technical assistance both in preventing and investigating of corruption.

Besides above, it has been suggested (Klitgaard 1998) that corruption is equal to monopoly plus discretion minus accountability. Based on this equity, the corruption problem can be reduced which is not only by enhancing the accountability, but also by limiting the monopoly and discretion of public officials. The limitation can be conducted by regulating and performing reward and punishment system (Klitgaard 1998). Gustav et al. (2014) added that limiting the discretion of public officials and political elites who have authority for regulating business or enterprise play a pivotal role in reducing corruption. The main reason for this is that discretion close to power, and based on dictum that power tends to corrupt, and absolute power corrupts absolutely.

Moreover, Pakdel, Darmichi, and Gholizadeh (2012) suggested that the best strategy to prevent corruption is through the identification and detection of the causes of corruption. For instance, related to this suggestion, when the corruption problems was the political system, so the political system is priority to be addressed. In terms of mindset and attitude improvement, Asian Development Bank (ADB) (2011) implied that integrity for all public officers and political elites needs to be grown. If it is related to bad system, the systems should be repaired so there is no chance for a person to commit acts of corruption.

Additionally, according to Pope (2000), the state who implemented National Integrity System (NIS) will be more effective in preventing corruption. Pope (2000) depicted the NIS as a house which has two foundations. They are public awareness and society's values. The two foundations must be supported by pillars. The pillars are: Legislature, Executive, Judiciary, Auditor General, Ombudsman, Watchdog Agencies, Public Service, Media, Civil Society, Private Sector, International Actors. The roof of NIS are Sustainable development, Rule of Law, dan Quality of Life (Pope 2000). By implementing National Integrity System will create the environment of anti-corruption which is not only supported by public institutions and private sectors but also by civil societies and all elements of country.

The other expert, Feldman (2014), stated that the corruption in the organization could be prevented by implementing anti corruption program. There are eleven elements of anti corruption programs. The eleven elements are: there is an anti corruption policy, code of ethics, training for employees, corruption risk assesment, good management, report system, internal control, monitoring, reward \& punishment policy, due diligence, and periodic review (Feldman 2014).

\section{Monitor}

According to the law number 30 of 2002, monitor effort will be held by the CEC 
as anti corruption agency to the state agency and government through assessing administrative system. When the results of the study found the potential for corruption, the CEC provide advice and recommendations to the minister or leaders of institutions for making changes. In the case of recommendations are not complied by the minister or leader of institution, the CEC will report to the President of Republic of Indonesia, House of Representatives, and Supreme Audit of the Republic of Indonesia.

\section{Discussions}

Currently, the task of monitor is conducting by Research and Development Directorate. The main objective of monitor is reviewing the system for reducing the potential of corruption. There are several institutions which had been monitored by the CEC. For instance, the Ministry of Finance, the Ministry of Religion, Ministry of Health, Ministry of Forestry, and the Ministry of Energy and Natrural Resources. There are a lot of recommendations, but most of them are making better system and using information and technology for preventing corruption.

\section{Coordination}

According to law number 30 of 2002, the CEC has authority to coordinate five items. First is coordinating the investigation, indichment, and prosecution of corruption cases. Secondly, by establishing report of activity the eradication corruption. Thirdly, by asking information about activity to the institutions as the stake holders. Fourthly, by hearing or meeting to the other law enforcement agencies. Lastly, by asking the report about the prevention of corruption from related instituons.

E. Supervision effort

The last strategy in eradicating corruption is through supervison efforts. According to the law number 30 of 2002, the CEC has the power for supervising, researching or studying which is not only to the other law enforcement agencies related to eradicate corruption, but also to the institutions related to the public services. In this case the CEC can take over the case of corruption (both indichment and prosecution stages) from police and attorney general. In fact, both coordination and supervision activities often be done together in the same time and place.

\section{Discussions}

Both coordination and supervision effort often used together. Coordination and supervision can be categorized as prevention and repression. In the prevention perspective, the CEC has conducted coordination and supervision in several sectors and some provinces. For instance, in the sector of mineral and coal, the CEC has carried out twelve provinces to push management of mineral and coal effectively and efficiently. The twelve provinces were Riau, Jambi, Bangka Belitung, South Sumatra, South Kalimantan, East Kalimantan, Central 
Kalimantan, West Kalimantan, North Maluku, South Sulawesi, Central Sulawesi, and South East Sulawesi. The main purpose of coordination and supervision are that mineral resources management should be for greatest welfare of the people as mandated on constitution 1945 (article 33).

In the term of repression, coordination and supervision were conducted by the CEC to create synergy and strengthen other law enforcement institutions such as Police and Attorney General. The CEC has limited resources and there were a lot public complaints about corruption cases which reported to Directorat of Public Complaints CEC. For example, in 2014 there were about nine thousands public complaints which is impossible the CEC to handle by itself. Another reason is that the CEC can not monopolize corruption case handling, since that the CEC had not established to eliminate the roles of existing of law enforcement institutions, but instead to improve and encourage other law enforcement institutions for eradicating corruption together (Annual report of CEC 2014).

\section{CONCLUSION}

To sum up, based on the previous descriptions, it can be concluded that there are at least five main factors that cause corruption in Indonesia. The first factor is political factor. The next factor is in-effective systems. The third factor is financial pressure. The fourth factor is weak law enforcement. The last factor is lack of integrity.
There are at least five strategies that need to be implemented for eradicating corruption in Indonesia. The strategies are repression, prevention, monitor, coordination, and supervison effort. The repression strategy will be effective if law enforcement to the prepetators of corruption creates deterrent effect. The prevention strategy will be more effective if all governments and bureaucrats perform the principles of good governance. In addition, it is necessary to prevent corruption by identifying the root causes of corruption, educating societies, limiting the discretion of elites, develop networking of international cooperation, promoting national integrity system, and anti corruption program.

Last but not least, to eradicate corruption in Indonesia, besides prevention and repression efforts have been made by the law enforcement agencies, there will be more optimal if monitor, coordination and supervision effort run effectively. The primary objective of monitor is creating system well in all government institutions for eliminating corruption chances. The coordination and supervison effort will be taken by the CEC to law enforcement agencies for purposing not only to handling corruption cases but also for preventing purposes.

\section{REFERENCES}

Annual report of Corruption Eradication Commission 2014, viewed 27 July 2015, retrieved from www.kpk.go.id;

Asian Development Bank 2008, Strategies for Business, Government and Civil Society to Fight Corruption in Asia and 
the Pacific. ADB/OECD Anti-Corruption Initiative for Asia and the Pacific, OECD/ ADB Publishing, Singapore;

Baltzan P, Phillips A, Lynch K,\& Blakey P 2010, Business Driven Information Systems, McGraw-Hill;

Barcham M, Hindess B, \& Larmour P 2012, CORRUPTION: Expanding the focus. Australian National University E Press Canberra ACT 0200, Australia;

Bertram I 2012, Detecting Corruption in Developing Countries: Identifying Causes/Strategies for Action, Stylus Publishing;

Brereton D 1999, Zero Tolerance and the NYPD: Has it Worked there and will it work here?, Canberra, Australian Institute of Criminology;

Feldman E 2014, Course Materials "Bribery and Corruption", ACFE Autin Texas USA;

Greene JA 1999, 'Zero Tolerance: A Case Study of Police Policies and Practices in New York City' Crime and Delinquency Journal, vol. 45, no. 2, pp. 171-187;

Gustav FP, Pardede R, \& Nazara S 2014, The Economic Choices: Facing the Next President, Center For Public Policy Transformation published;

Hamzah, A 2006, Pemberantasan Korupsi Melalui Hukum Pidana Nasional dan Internasional (Eradicating Corruption through National and International Criminal Law), Revison Edition, Rajawali Pers Jakarta.
Heidenheimer A, \& Johnston M 2008, Political Corruption: Concepts \& Contexts. Third Edition, Transaction Publishers, New Brunswick, New Jersey, USA.

Kasim A2013, Globalization and Transparency: Models for Building Public Trust, PA Times International Supplement, vol. 36, no. 1, pp.11-19;

Klitgaard R. 1998, 'International Cooperation Against Corruption' Finance \& Development;

Komarudin 2006, Korupsi dan Reformasi Birokrasi di Indonesia (Corruption and Bureaucratic Reform in Indonesia), Demokrasi \& HAM, The Habibie Center, vol. 5 , no. 3 ;

Kuncoro A 2006, 'Corruption and Business Uncertainty in Indonesia', ASEAN Economic Bulletin, vol. 39, no. 1, pp.1130

Kwok 2007, Formulating an Effective AntiCorruption Strategy - The Experience of Hongkong ICAC, viewed 26 July 2015, retrieved from http://www.unafei.or.jp/ english/pdf/PDF rms/ no69/16 P196201.pdf;

Law No. 30 Year 2002 about Corrution Eradication Commission of the Republic of Indonesia;

Macmillan J 2011, Reforms and Public Corruption: Why Indonesia's AntiCorruption Agency Strategy Should be Reformed to Effectively Combat Public Corruption' Memory International Law Review, vol. 25, pp.587-630; 
Margareth A. 2015, 'Accountability key to political party funding: ICW', Jakarta Post, 11 March;

Newman N 2011, 'Indonesia: Telling Lies' World Policy Journal, vol. 28, 82;

Pakdel A, Damirchi QV, \& Gholizadeh H 2012, 'Corruption and Anti-Corruption Policies in Developing Countries ', Interdisciplinary Jounal of Contemporary Research in Business, vol. 3, no. 9, pp.194-203;

Pope J 2000, Confronting Corruption: The Elements of National Integrity System, Transparency International;

Rama M 2012, 'Corporate Governance and Corruption: Ethical Dilemmas of Asian Business Groups. Centre for Corporate Governance, University of Technology Sydney, Sydney, Australia', Journal Business Ethics, vol. 109,pp.501-519;

Suroso J 2014, Jejak Korupsi, Politisi \& Klan

Cikeas (Corruption Path, Politican \& Cikeas Clant), 1st edn, Soegeng Sarjadi Syndicate, Jakarta;

Tanthowi PU, Antoni RJ, Kurniawan R, \& Sustanto J 2005, Membasmi Kanker Korupsi (Eradicate the cancer of corruption). Pusat Studi Agama dan Peradaban Muhammadiyah, Jakarta;

Transparency International 2015, Corruption Perceptions Index 2014, retrieved from http://www.transparency.org at 25 July 2015;
Turner J, Mock TJ, Srivastava RP 2003, An Analysis of the Fraud Triangle. University of Southern California publishing.

Yap Kioe Sheng 2015, What is Good Governance? in United Nations Economic and Social Commission for Asia and Pacific retrieved from http:// www.unescap.org at 26 July 2015. 